\title{
Varying market conditions on the New York Stock Exchange and their effects on non-USA markets
}

\author{
D.J. Bradfield \\ Department of Statistical Sciences, University of Cape Town, Cape Town 8000, Republic of South Africa
}

\author{
Received December 1991, accepted March 1993
}

\begin{abstract}
The effects of various market conditions of the New York Stock Exchange (NYSE) on non-USA markets are investigated in this article. On the basis of an empirical investigation, evidence is presented which suggests that the influence of the NYSE on non-USA markets differs during different market conditions of the NYSE. For example, it was found that during declining market conditions on the NYSE the influence was greater on non-USA markets than during rising market conditions on the NYSE. A model designed to yield detailed risk statistics of individual non-USA securities was also implemented to investigate the impact of various market conditions of the NYSE.

In hierdie artikel word die gevolge van verskeie marktoestande van die New Yorkse Effektebeurs (NYE) op nie-VSA markte ondersoek. Op grond van ' $n$ empiriese ondersoek word bewys dat die invloed van die NYE op nie-VSA markte gedurende veranderende marktoestande van die NYE wissel. Daar is byvoorbeeld bevind dat gedurende dalende marktoestande op die NYE die impak op nie-VSA markte groter is as gedurende stygende marktoestande. 'n Model war ontwerp is om gedetailleerde risikostatistieke van individuele nie-VSA aandele op te lewer, is ook toegepas om die impak van verskeie marktoestande van die NYE te ondersoek.
\end{abstract}

\section{Introduction}

There is little doubt that the NYSE is considered one of the most internationally influential stock exchanges in the world, and that movements of the NYSE consequently have an impact on stock markets world-wide. Agmon (1973) on the basis of empirical results, concludes that the USA market is the connecting link between the non-USA markets he investigated, namely the United Kingdom, Germany and Japan. Adler \& Horesh (1974) also refer to the US market as being the multi-regional market. Agmon $(1972,1973)$ argues further that the US market plays a significant role in generating price changes in non-USA markets. The events of October 1987 (and to a lesser extent October 1989) when prices on the NYSE fell dramatically causing almost all non-USA markets to fall in unison, further highlighted this assertion. Although the October 1987 crash emphasized the existence of a significant relationship between the NYSE and non-USA markets, it is not clear whether the magnitude of the crash simply made this relationship easier for investors to observe, ${ }^{1}$ or whether this relationship undergoes a fundamental change during sharp movements in the NYSE. An issue of interest (and the focus of this article) therefore, is to determine whether a stable relationship exists between the NYSE and other non-USA markets or whether these relationships differ during different phases of the NYSE. ${ }^{2}$

Much debate in literature has focussed on whether international markets can be thought of as being either segmented or a perfectly integrated single market. Errunza \& Losq (1985) conducted a study incorporating the US market as well as nine lesser developed countries ${ }^{3}$ (LDCs). On the basis of their results they find tentative support for a mild segmentation hypothesis. This hypothesis assumes that the world's various capital markets do not behave as if they were a perfectly integrated efficient single market, and that this behaviour is caused by the fact that many countries restrict free access to capital markets. Various other aspects of the international segmentation-integration issue have been investigated by Solnik (1974), Black (1974), Adler \& Dumas (1975), Grauer et al. (1976), Glenn (1976), Stehle
(1977), Stapleton \& Sabrahmanyam (1977), Stulz (1981a, 1981b) and Bradfield et al. (1988). Most of the above researchers however have focussed on various aspects of asset pricing under conditions of market equilibrium.

In this article a more modest objective is pursued: here the focus is concentrated primarily on investigating the impact of various phases of the USA market on the risk of non-USA markets.

In the first section of this article the relationships between a sample of three non-USA stock markets and the NYSE are investigated empirically over various market conditions of the NYSE. The three sampled non-USA markets are: the London Stock Exchange (LSE), the Tokyo Stock Exchange (TSE) and the Johannesburg Stock Exchange (JSE). The investigation is conducted using a simple linear model relating the return on the non-USA market to the return on the USA market. Here consideration is given to whether the relationship between these non-USA markets and the NYSE undergœes a fundamental change during different market conditions on the NYSE.

In the second section of this anicle the influence of various phases of the NYSE on individual non-USA securities (rather than entire market indices) is investigated empirically. This analysis is conducted with the aid of a model originally proposed by Agmon (1973) which can be used to obtain detailed risk components for non-USA securities.

The notion of risk was originally dealt with in two main conceptual frameworks, the state-preference framework developed by Arrow (1951) and later Debreu (1959), and the mean-variance framework developed by Markowitz (1952). The state-preference framework approach assumes that objects of choice yield payoffs offered in different states of nature. While this framework is useful for investigating theoretical issues, it lacks empirical content due to the difficulty in quantifying all the payoffs offered in different states of nature. The pioneering work of Markowitz $(1952,1959)$ on portfolio selection in the mean-variance framework however, paved the way for the development of 
Capital Market Theory in the mean-variance framework. Consequently the variance of a series of retums has been well-entrenched in literature as a measure of risk. It is within this framework that the ensuing analysis is conducted.

\section{Data}

The data used in the investigation consisted of the monthly return series on the Dow-Jones Index, the UK Financial Times Index, the Nikkei-Dow (Tokyo) Index and the JSEActuaries Overall Index. These indices were all converted to US dollar denominations using the relevant prevailing exchange rates. Further a sample of 30 securities listed on the JSE were subjectively sampled for the investigation in the second section. ${ }^{4}$ The period of study ranged from September 1978 to November 1987.

\section{Effect of the NYSE on the risk of non-USA markets}

The underlying model used in this investigation draws on the work of Agmon (1973). Agmon (1973) asserts that the relationship between non-USA markets and the USA market can be summarized by regressing the returns of the nonUSA market index on the returns of the USA market index and interpreting the resultant slope coefficient. This approach $^{5}$ in essence purports a linear model of the form:

$R_{\mathrm{ml}}^{L O C}=\alpha+\beta R_{\mathrm{mt}}^{\mathrm{USA}}+\mathrm{c}_{\mathrm{i}}$

where $R_{m t}^{L O C}$ is the dollar return on the non-USA market at time $t$;

$\mathrm{R}_{\mathrm{mt}}^{\mathrm{USA}}$ is the dollar return on the USA market index at time t;

and $\quad \alpha$ and $\beta$ are the regression coefficients.

Inspection of (1) suggests the usual decomposition of risk (see Markowitz, 1959) within this proposed framework, namely

$\sigma^{2}\left[R_{m l}^{L O C}\right]=\beta^{2} \sigma^{2} R_{m s}^{U S A}+\sigma^{2}\left(e_{l}\right)$

which can be interpreted as:

Local market risk = USA market risk + unique risk ${ }^{6}$

where 'Local market risk' is the total risk of the market index, 'USA market risk' is the amount of risk attributable to movements in the USA market index; and 'unique risk' is the amount of risk unexplained by movements in the USA market index.

In order to investigate the behaviour of the risk of nonUSA stocks using model (1) during different market conditions of the NYSE, the return data was partitioned according to various criteria designed to capture three different market conditions of the NYSE. The three market conditions on the NYSE considered here are:

1. Rising/positive returns on the NYSE.

2. Declining/negative returns on the NYSE.

3. Substantial movements on the NYSE.

The selection criterion used to capture these market conditions are outlined below.

\section{Rising/positive returns on the NYSE}

This criterion resulted in retum data being partitioned according to only positive ${ }^{7}$ movements of the Dow-Jones Index. This partitioning amounted to matching up dollar returns of the non-USA markets in months when the dollar returns on the Dow-Jones Index was positive.

\section{Declining/negative returns on the NYSE}

Similarly this criterion resulted in dollar return data on the non-USA indices being matched to dollar return data on the Dow Jones Index only in months when the return on the Dow Jones Index was negative.

\section{Substantial movements on the NYSE}

Substantial movements resulted in return data being used only in months where the absolute value of the dollar return on the Dow-Jones Index exceeded $6 \%^{8}$ per month. This amounted to matching up retums when the Dow-Jones Index exceeded $6 \%$ in absolute value.

Summary risk statistics for the three non-USA stock markets estimated from model (1) using the corresponding reduced return series are shown in Table 1 .

The risk statistics for the sampled non-USA markets shown in Table 1 suggest that the relationships between non-USA markets and the NYSE do indeed differ over different market conditions on the NYSE.

In the first panel of Table 1 are shown the statistics that captured the relationship between the non-USA markets and the NYSE using the entire series of returns over the sampled

Table 1 Summary risk statistics estimated over various market conditions on the NYSE

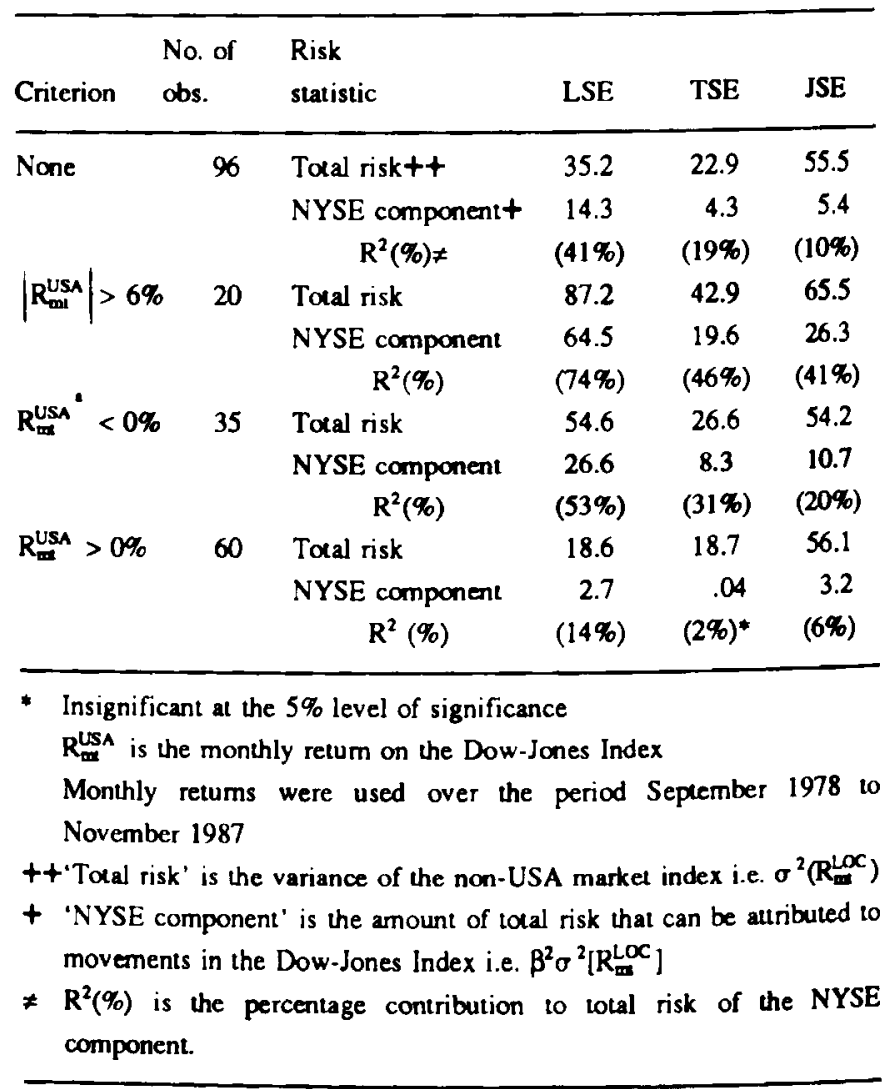


period, that is, with no restriction on the magnitude of returns on the Dow-Jones Index. Of the three sampled nonUSA markets the LSE is seen to have the largest proportion of its risk associated with movements on the NYSE, namely $41 \%$, followed by the TSE and the $\mathrm{JSE}^{9}$ having $19 \%$ and $10 \%$ respectively.

Shown in the second panel of Table 1 are the resulting statistics for the criterion where returns are only considered during times of substantial movements on the NYSE (that is when returns on the Dow-Jones Index exceeded $6 \%$ per month in absolute value). From the results shown in the second row of Table 1 it is evident that the proportion of risk that can be explained by the NYSE (i.e. the $R^{2}$ ) for all three non-USA markets are significantly higher during times of substantial movements on the NYSE, with the LSE exhibiting an $\mathrm{R}^{2}$ of as high as $74 \%$ with the NYSE here. Conversely this implies that only $26 \%$ of the movements of the UK index can be attributed to factors unrelated to movements on the NYSE here. This evidence suggests that nonUSA markets are far more susceptable to movements on the NYSE during times when the movements on the NYSE are substantial.

Shown in the third panel of Table 1 are the risk statistics for the criterion where returns are only considered during times when the monthly returns on the Dow-Jones Index were negative. By contrast shown in the last panel of Table 1 are the correlation coefficients computed only during times when the returns on the Dow-Jones Index were positive. The results for the 'positive' criterion on the NYSE show that the proportion of risk attributable to the NYSE is significantly smaller than usual for all three non-USA markets. By contrast the results for the 'negative' criterion on the NYSE shown in the third panel indicate that the proportion of risk attributable to the NYSE for all three nonUSA markets are consistently larger than usual for all these non-USA markets, although not as large as the case for the criterion considering only substantial returns on the NYSE. This evidence seems to suggest that the NYSE has a greater influence on non-USA markets during times of declining market conditions than during times of rising market conditions on the NYSE.

In the next section the influence of the NYSE on a sample of individual non-USA securities is examined. Once again the impact of various phases of the NYSE on the risk components of individual securities is examined. A model similar in spirit to that proposed by Agmon (1973) and Errunza \& Losq (1985) is used to give more information concerning the risk components of non-USA securities in the ensuing analysis.

\section{Effect of the NYSE on the risk of individual securi- ties}

The same criteria used to investigate the effects of different market conditions on the NYSE on the sample of non-USA market indices were also used here for individual securities. The sample of 30 securities used in this analysis was selected from the JSE (these securities were chosen to typify non-USA securities in the ensuing analysis).

The two-factor model used in this section is identical to the model originally proposed by Agmon (1973) to identify the effect of various 'country' factors on the risk of nonUSA markets. The model is essentially similar to the model used by Errunza \& Losq (1985) to investigate the notion of segmentation/integration of world markets and is also similar in spirit to the model used by Lessard $(1973,1974)$, Solnik (1974) and Stehle (1977) who also investigated the risk across world markets.

The model outlined below does not require any assumption abouts its process generating returns (see Stehle, 1977). This model, in essence, relates the return of a security listed on a non-USA market, (henceforth referred to as the local market) to the retum on a local market index, plus the return on a US market index. In order to obtain tractable expressions for the risk components, i.e. local market risk, US market risk and unique risk, the vector of local and US market returns are orthogonalized. This amounts to removing the effect of the US index from the returns of the local index. This can be simply achieved by regressing the returns of the local index on the returns of the US index, and using the resultant residuals to represent the local index with the effects of the US index removed.

The model, henceforth referred to as the multi-market model can be written as

$R_{i t}=a_{i}+\beta_{i}^{L O C-U S A} R_{m t}^{\text {LOC-USA }}+\beta_{i}^{\text {USA }} R_{m t}^{\text {USA }}+e_{i t}$

where $R_{i t}$ is the retum on share $i$ at time $t$; $a_{i}, \beta_{i}^{L O C-U S A}$ and $\beta_{i}^{U S A}$ are coefficients unique to share $\mathrm{i}$;

$\mathrm{R}_{\mathrm{mt}}^{\mathrm{USA}}$ is the retum on the US market index at time $\mathrm{t}$; $R_{m t}^{L O C-U S A}$ is the residual local market index retum at time $\mathrm{L}$ obtained by regressing the retums of the local market index on the US market index returns and; the following assumptions regarding the $\mathrm{e}_{\mathrm{i}}$ are made: $E\left(e_{i t}\right)=0$

$$
\begin{array}{ll}
\operatorname{COV}\left(\mathrm{e}_{\mathrm{it}} ; \mathrm{e}_{\mathrm{is}}\right)=0 & \text { for } \mathrm{t} \neq \mathrm{s} \\
\operatorname{COV}\left(R_{\mathrm{mt}}^{\mathrm{SA}} ; \mathrm{e}_{\mathrm{i}}\right)=0 & \text { for all } \mathrm{t} \\
\operatorname{COV}\left(R_{\mathrm{ml}}^{\mathrm{LC}-U \mathrm{UA}} ; \mathrm{e}_{\mathrm{it}}\right)=0 & \text { for all } \mathrm{t} .
\end{array}
$$

The components of risk for security i can be obtained by considering the expression for the variance of security i's returns, i.e.

$$
\begin{aligned}
& \operatorname{Var}\left(R_{i t}\right)=\operatorname{Var}\left(a_{i}+\beta_{i}^{\text {OC-USA }} R_{m t}^{\text {LOC-USA }}+\beta_{i}^{\text {USA }} \mathbf{R}_{m i}^{\text {USA }}+\mathbf{e}_{i t}\right) \\
& =\operatorname{Var}\left(a_{i}\right)+\beta_{i}^{\text {OC-USA }}{ }^{2} \operatorname{Var}\left(R_{m t}^{\text {LOC-USA }}\right)+\beta_{i}^{\text {USA }}{ }^{2} \\
& \operatorname{Var}\left(R_{\mathrm{mi}}^{\mathrm{USA}}\right) \\
& +2 \beta^{\text {LOC-USA }} \beta_{i}^{\text {USA }} \beta_{i}^{\text {USA }} \operatorname{COV}\left[R_{m t}^{\text {LOC-USA }} ; R_{m i}^{\text {USA }}\right]+ \\
& \operatorname{Var}\left(\mathrm{e}_{\mathrm{it}}\right)
\end{aligned}
$$

Since $a_{i}$ is a constant $\operatorname{Var}\left(a_{i}\right)=0$ and; by construction $\operatorname{COV}\left(\mathrm{R}_{\mathrm{mt}}^{\mathrm{LOC}-U S A} ; \mathrm{R}_{\mathrm{mt}}^{\mathrm{USA}}\right)=0$; the above expression simplifies to:

$$
\begin{aligned}
\operatorname{Var}\left(R_{i t}\right) & =\beta_{i}^{O C-U S A}{ }^{2} \operatorname{Var}\left(R_{m l}^{\text {LOC-USA }}\right)+\beta_{i}^{U S \Lambda^{2}} \operatorname{Var}\left(R_{m t}^{\text {USA }}\right) \\
& +\operatorname{Var}\left(\mathrm{e}_{\mathrm{it}}\right) .
\end{aligned}
$$

Thus the above expression can be interpreted as:

Total risk = Local market risk only + USA market risk

$$
+ \text { unique risk. }
$$


The data used in the empirical investigation consisted of the monthly retum series of 30 subjectively chosen securities on the JSE as well as the JSE-Actuaries Overall Index (representing the local market index) and the Dow-Jones Index (representing the US market index). The period of study ranged from September 1978 to November 1987. The 30 securities were subjectively chosen to represent a crosssection of securities having varying proportions of incomes derived from overseas markets. For example, the sample ranged from securities having a major proportion of their income derived from overseas markets on one extreme, to securities having all of their income derived locally, on the other extreme. A list of the sampled securities is shown in the Appendix.

The multi-market model (2) was estimated using the return data of each of the 30 securities over the period September 1978 to November 1987.

The treatment of exchange rates are considered from two perspectives: firstly the investigation was conducted with all variables in model (2) expressed in the same currency returns via the rand/dollar exchange rate (case 1). This treatment suggests that the security price changes are influenced by investors who are concemed with the impact of changes associated with the fundamental value of the NYSE. However, since the inflow and outflow of investment capital on the JSE is restricted ${ }^{10}$ the rand value return of the DowJones Index may not be the concern of local investors. The possibility that the rand price changes of local securities are linked to the dollar movements in the Dow-Jones Index was also considered here (case 2). This treatment suggests that investors pricing securities on the JSE are solely influenced by the sentiment portrayed by dollar movements of the Dow-Jones Index.

The results of running model (2) on each of the 30 securities for case 2 show a somewhat weaker relationship with the NYSE on average than that for case 2 described above." Hence only the results obtained by considering case 2 will be presented here.

More specifically the particulars of considering case 2 amounts to running model (2) using the variables having the following currency returns:

$R_{m i}^{\text {USA }}$ represents the series of dollar returns on the Dow-Jones Index;

$R_{m e}^{\text {LOC-USA }}$ represents the series of rand returns on the JSE-Actuaries Overall Index with the dollar effect of the Dow-Jones Index removed; and

$R_{i t}$ represents the series of rand returns on share $i$.

It is clearly not the coefficients of the model that are of major concern here, but rather the decomposition of total risk into the various components of risk so that the influence of the NYSE on the risk of non-USA stocks can be determined. For each of the criteria representing the various phases of the NYSE the risk components were averaged across the 30 securities. These risk components are expressed as a percentage of total risk.

The results showing the percentage contribution of the NYSE risk component in the first column of Table 2 are of primary importance to this investigation. From Table 2 it is evident that the results for the individual securities are consistent with the results obtained for the market indices in
Table 2 Average risk components expressed as a percentage of total risk

\begin{tabular}{|c|c|c|c|}
\hline \multirow[t]{2}{*}{ Criterion } & \multicolumn{3}{|c|}{$\begin{array}{l}\text { Average risk components } \\
\text { using model (1) }\end{array}$} \\
\hline & $\begin{array}{c}\text { NYSE } \\
\text { component }\end{array}$ & $\begin{array}{c}\text { Local } \\
\text { component }\end{array}$ & $\begin{array}{l}\text { Unique } \\
\text { component }\end{array}$ \\
\hline None & $5.36 \%$ & $28.29 \%$ & $66.35 \%$ \\
\hline$\left|R_{m}^{\text {USA }}\right|>6 \%$ & $17.25 \%$ & $20.01 \%$ & $62.74 \%$ \\
\hline $\mathrm{R}_{\mathrm{mit}}^{\text {USA }}<0 \%$ & $9.85 \%$ & $29.67 \%$ & $60.47 \%$ \\
\hline $\mathrm{R}_{\mathrm{m}}^{\mathrm{USA}}>0 \%$ & $2.65 \%$ & $28.96 \%$ & $68.39 \%$ \\
\hline \multicolumn{4}{|c|}{$\begin{array}{l}\text { a. Computed using the expression } \beta^{\text {USA }}{ }^{2} \text { var }\left(R_{m}^{\text {USA }}\right) \\
\left.\text { b. Computed using the expression } \beta^{\text {Loc.usA }} \text { var( } R_{m}^{\text {LOC.USA }}\right)\end{array}$} \\
\hline
\end{tabular}

the previous section. ${ }^{12}$. In particular, for the criterion $\left|\mathbf{R}_{\mathrm{mt}}^{\text {USA }}\right|$ $>6 \%$, the NYSE risk component is largest, that is $17.25 \%$ of the total risk on average.

By contrast over the whole period (i.e. with no restriction on the returns of the Dow-Jones Index) the NYSE risk component was only $5.36 \%$ of the total risk on average.

It thus appears that during times of both substantial rises and declines of the NYSE, the sampled shares tend to be driven to a greater extent by movements of the NYSE, than at other times.

The findings shown in Table 2 for NYSE positive and negative market phases reveal that during times when the NYSE was rising, on average only $2.65 \%$ of the risk of the sampled stocks were related to these NYSE movements, while during times when the NYSE was declining, on average $9.85 \%$ of the risk of the sampled stocks was related to these NYSE movements. It thus appears as if the JSE stocks generally respond more strongly to declines rather than rises in the NYSE.

A further point worth noting is that the component of local risk shown in column 2 remains consistently large over the various market conditions on the NYSE. This component has been referred to as the 'country factor' by Agmon (1973), Errunza (1979), Errunza \& Losque (1985), Lessard (1944) and Solnik (1974) who all found that this factor seems to be strong in their studies.

The risk components shown in Table 2 were averaged across all 30 securities in the sample, however, it was found that only 19 of these 30 securities had significant $\hat{\beta}^{\text {USA }}$ coefficients over general market conditions on the NYSE. In order to determine to what extent these shares in particular were influenced by the various NYSE market conditions, the resulting risk components for the criteria listed in Table 2 were averaged across only these 19 securities. These results are shown in Table 3.

From Table 3 it is evident that the percentage of risk explained by the NYSE (shown in the first column) is significantly larger than those shown in Table 2 for the criteria $\left|R_{m i}^{\text {USA }}\right|>6 \%$ and $R_{m t}^{\text {USA }}<0$. This implies that the securities that are significantly related to the NYSE over general market conditions (i.e. with significant $\hat{\beta}^{\text {USA }}$ coefficients) are influenced to a greater extent by the NYSE in the abovementioned NYSE market conditions. However for the 
Table 3 Average risk components of shares with significant $\beta^{\text {USA }}$ coefficients expressed as a percentage of total risk

\begin{tabular}{|c|c|c|c|}
\hline \multirow[t]{2}{*}{ Criterion } & \multicolumn{3}{|c|}{$\begin{array}{c}\text { Average risk components } \\
\text { using model (1) }\end{array}$} \\
\hline & $\begin{array}{l}\text { NYSE } \\
\text { component }\end{array}$ & $\begin{array}{l}\text { Local } \\
\text { component }\end{array}$ & $\begin{array}{l}\text { Unique } \\
\text { component }\end{array}$ \\
\hline None & $7.88 \%$ & $37.73 \%$ & $54.38 \%$ \\
\hline$\left|\mathrm{R}_{\mathrm{mat}}^{\mathrm{USA}}\right|>6 \%$ & $25.33 \%$ & $24.97 \%$ & $49.70 \%$ \\
\hline $\mathrm{R}_{\mathrm{m}}^{\mathrm{USA}}<0 \%$ & $14.26 \%$ & $37.62 \%$ & $48.12 \%$ \\
\hline $\mathrm{R}_{\mathbf{m}}^{\mathrm{USA}}>0 \%$ & $3.25 \%$ & $37.93 \%$ & $58.82 \%$ \\
\hline
\end{tabular}

criteria $\mathrm{R}_{\mathrm{mt}}^{\text {USA }}>0$ the improvement from $2.65 \%$ on average (for 30 shares) to $3.25 \%$ on average (for the 19 shares) is hardly significant. This result reveals that the relationship found during positive and negative market conditions on the NYSE shown in Table 2 are not significantly biased by the eleven shares with insignificant $\hat{\beta}^{\text {USA }}$ coefficients. Hence the conclusion here is that even shares with significant $\widehat{\beta}^{\text {USA }}$ coefficients did not respond significantly during times of rises in the NYSE. A further interesting finding that is worth noting, is that for all criteria the percentage of local risk shown in Table 3 is approximately 10\% higher than the corresponding percentage of local risk shown in Table 2 . This tends to imply that, interestingly, shares with large NYSE risk components also have large local risk components.

\section{Conclusion}

The findings of this investigation has several implications for investors in non-USA markets. Firstly the results presented here suggest that the relationship between non-USA markets and the NYSE does indeed differ during different markel conditions on the NYSE. In particular it was found that the relationships between non-USA markets and the NYSE is significantly stronger during times of substantial movements of the NYSE. This relationship was also found to be stronger during negative market conditions on the NYSE than during positive market conditions on the NYSE. Furthermore use of a model for investigating issues which have an impact on the risk structure of non-USA securities reveals that the findings for individual non-USA securities are consistent with the above findings for market indices.

\section{Notes}

1. A stable/constant relationship implies for example that a large percentage move on the NYSE is associated with a proportionately large movement on the non-USA market.

2. Black (1972) and Levy (1974) originally suggested that the traditional beta coefficients of individual securities (linking individual security retums to a local market index) changed during bull and bear market conditions on the NYSE. Fabozzi \& Francis (1977) however, provided empirical evidence on the NYSE which indicated that betas were unchanged over bull and bear market conditions.

3. The nine LDCs are: Argentina, Brazil, Chile, Greece, India, Korea, Mexico, Thailand and Zimbabwe.
4. The $\mathbf{3 0}$ securities were subjectively chosen to represent a cross-section of securities having varying proportions of incomes derived from overseas markets. Furthermore only well-traded securities were favoured to minimize estimation problems caused by thin trading in smaller markets.

5. While this approach does assume certain linkages between the USA market and non-USA markets the notion of causality is not addressed.

6. On the basis of empirical results Agmon (1973) concludes that the risk unique to non-USA markets is not generally related to movements of other non-USA markets.

7. Fabozzi \& Francis (1977) suggest using this criterion to identify a 'bull' market. Lindahl-Steven (1980) suggests a similar approach to identify 'bull' and 'bear' markets with the exception that the risk-free rate be used to delineate these market conditions. In this article however no definition of the concept of 'bull' and 'bear' markets is attempted.

8. This value is approximately one standard deviation from the mean market return on the Dow-Jones Index.

9. It is worth noting that sanction campaigns against South Africa is likely to have had a dampening effect on the relationship between the NYSE and the JSE.

10. South African investors are restricted from investing abroad, furthermore the inflow of capital to South Africa has been restricted by sanctions campaigns.

11. The average $\hat{\beta}^{U A A}$ coefficient for case 1 was 0.07 with an average $p$-value of 0.378 (for the hypothesis $\widehat{\beta}=0$ ). By contrast the average $\hat{\beta}^{U S A}$ coefficient for case 2 was 0.43 with an average $p$-value of 0.146 .

12. Although the same patterns are evident across the various market conditions on the NYSE, the proportionate contribution of the NYSE component of risk for the individual securities is substantially smaller than for the market indices. This decrease in the proportionate contribution of the NYSE risk component for securities can be explained by the fact that market indices by construction are well diversified, resulting in substantially smaller components of unique risk.

\section{References}

Adler, M. \& Dumas, B. 1975. 'Optimal international acquisitions', Journal of Finance, Vol. 30: 1-19.

Adler, N. \& Horesh, R. 1974. 'The relationship among equity markets: Comment', Journal of Finance, Vol. 29: 1311-1317.

Agmon, T. 1972. 'The relationship among equity markets: A study of share price co-movements in the United States, United Kingdom, Germany and Japan', Journal of Finance, Vol. 27: 839-855.

Agmon, T. 1973. 'The country risk. The significance of the country factor to share price movements in the United Kingdom, Germany and Japan', Journal of Business, Vol. 46: 24-32.

Arrow, KJ. 1951. 'Altemative approaches to the theory of choice in risk-taking situations', Econometrica, Vol. 19: 404-437.

Black, F. 1970. 'Capital market equilibrium with restricted borrowing', Journal of Business, Vol. 45: 444-455.

Black. F. 1974. 'Intemational capital market equilibrium with investment barriers', Journal of Financial Economics, Vol. 1: $337-352$.

Bradfield, D.J., Affleck-Graves, J.F. \& Barr, G.D.I. 1988. 'Asset pricing in small markets - the South African case', SA.JBus. Manage., Vol. 19: 11-21.

Debreu, G. 1959. The theory of value. New York: John Wiley. 
Errume, V. L Losq. E. 1985. 'International asset pricing under mild segmentation: Theory and test'. Jowmal of Finance, Vol. 40: $105-124$.

Errunza, V. 1979. 'Efficiency and the program to develop capital markets - the Brazilian experience', Journal of Banking and Finance, Vol. 3: 355-382.

Fabozzi. F.J. \& Francis, J.C. 1977. 'Stability tests for alpha's and beta's over bull and bear market conditions', Journal of Finance, Vol. 32: 1092-1099.

Gkenn. D. 1976. 'Super premium security prices and optimal corporate financing', Journal of Finance, Vol. 32: 479-492.

Graver, F.L., Litzenberger, R.H. \& Stehle, R.E. 1976. 'Sharing rules and equilibrium in an international capital market under uncertainty", Joumal of Financial Economics, Vol. 3: 233-256.

Lessard. D. 1973. 'International portfolio diversification: A multivariate analysis for a group of Latin American countries', Jowrnal of Finance, Vol. 28: 619-633.

Lessard, D. 1974. 'World, national and industry factors in equity returns', Journal of Finance, Vol. 29: 379-391.

Levy, R.A. 1974. 'Beta coefficients as predictors of return', Financial Analysts Journal, Vol. 30: 61-69.

Lindahl-Stevens, M. 1980. 'Redefining bull and bear markets', Financial Analysts Journal, Vol. 36: 76-77.

Markowitz, H.M. 1952. 'Portfolio selection'. Jowrnal of Finance. Vol. 7: 71-91.

Markowitz, H.M. 1959. Portfolio selection, efficient diversification of investmenss. New York: John Wiley.

Solnik, B.H. 1974. 'The international pricing of risk: An empirical investigation of the world market structure. Journal of Finance, Vol. 29: 365-378.

Stapleton, R.C. \& Subrahmanyam, M.G. 1974. 'Market imper- fections, capital market equilibrium and corporation finance', Jownal of Finance, Vol. 32: 307-319.

Stehle, R. 1977. 'An empirical lest of the altemative hypothesis of national and international pricing of risky assets', Journal of Finance, 32: 493-502.

Stulz, R. 1981a. 'A model of international asset pricing', Jownal of Financial Economics, Vol. 9: 383-403.

Stulz. R. $1981 \mathrm{~b}$. 'On the effects of barriers to international investment', Jowrnal of Financial Economics, Vol. 36: 923-934.

\section{Appondlx}

Share name

$\begin{array}{ll}\text { Rusplat } & \text { Rembrandt } \\ \text { De Beers } & \text { Lorraine } \\ \text { Dorbyl } & \text { Lyd Plat } \\ \text { Anglo America } & \text { Sappi } \\ \text { Barlows } & \text { Highveld } \\ \text { Kloof } & \text { Reunen } \\ \text { Bracken } & \text { SA Eagle } \\ \text { Wooltru } & \text { SA Brews } \\ \text { AECI } & \text { Johnnies } \\ \text { Pick 'n Pay } & \text { Amcoal } \\ \text { Randfontein } & \text { Fedfund } \\ \text { Fedfood } & \text { Toyota } \\ \text { Mcarthy } & \text { Tradegro } \\ \text { Amaprop } & \text { Rex True } \\ \text { Barclays } & \text { LTA }\end{array}$

